\title{
The Economy of Puberty and Early Pregnancy Diagnosis in Nellore and Nellore X Angus Females
}

\author{
Frederich Diaz-Rodriguez
}

University of São Paulo, School of Veterinary Medicine and Animal Science, Department of Nutrition and Animal Production, Pirassununga, São Paulo, Brazil.

E-mail: frederichdiro@gmail.com

Oscar Alejandro Ojeda-Rojas

University of São Paulo, School of Veterinary Medicine and Animal Science, Department of Nutrition and Animal Production, Pirassununga, São Paulo, Brazil.

E-mail: alejandro.ojeda@usp.br

Guilherme Pugliesi

University of São Paulo, School of Veterinary Medicine and Animal Science, Department of Animal Reproduction, Pirassununga, São Paulo, Brazil. E-mail: pugliesi_vet@hotmail.com

Marcos Vinícius Ferraz Junior

Federal University of Amazonas, College of Animal Science, Parintins, Amazonas, Brazil.

E-mail: ferrazmvc@gmail.com

Mario Binelli

University of Florida, Institute of Food and Agricultural Sciences, Animal Sciences

Department, Gainesville, Florida, United States. E-mail: binelli@usp.br

Alexandre Vaz Pires

University of São Paulo, Luiz de Queiroz College of Agriculture, Department of Animal

Sciences, Piracicaba, São Paulo, Brazil. E-mail: pires.1@usp.br

Mariana Bombo Perozzi Gameiro

University of São Paulo, School of Veterinary Medicine and Animal Science, Department of Preventive Veterinary Medicine and Animal Health (VPS), Pirassununga, São Paulo, Brazil.

E-mail: marianaperozzi@gmail.com

Augusto Hauber Gameiro (Corresponding Author)

University of São Paulo, School of Veterinary Medicine and Animal Science, Department of Nutrition and Animal Production, Pirassununga, São Paulo, Brazil. E-mail: gameiro@usp.br 
Received: Sep. 22, 2019

doi:10.5296/jas.v8i1.15736
Accepted: Oct. 29, 2019

Published: Oct. 30, 2019

URL: https://doi.org/10.5296/jas.v8i1.15736

\begin{abstract}
Cash flows were developed to verify, over a 15-year period, the effect of anticipating puberty (using feedlot and nutritional supplementation) and pregnancy diagnosis (using conventional transrectal ultrasound or color Doppler) on the net present value (NPV) of farms dedicated to producing Nellore (Bos taurus indicus) or Nellore x Angus (Bos taurus taurus) crossbred calves. In addition, in order to determine the effect of input prices on the viability of the enterprise, an economic analysis was carried out with the historical prices paid and received by Brazilian farmers over a 10-year period. Multiple regression was the statistical technique used to construct models that adequately described the relationships between the various independent variables (genetic group, nutritional strategy, pregnancy diagnosis technique, and relative market prices) and the dependent variable, which was represented by the NPV economic indicator. The fact that Nellore $\mathrm{x}$ Angus females reached puberty earlier than Nellore females favored the number of weaned calves and therefore, the NPV of the enterprise. Conducting pregnancy diagnosis earlier increased the project's NPV by R $\$ 2.7$ million $(\approx$ US\$ 0.77 million). Although feedlot and supplementation represent $65 \%$ of production costs, obtaining reasonable growth rates by providing animals with proper feeding improved the NPV significantly. Finally, after analyzing the effect of historical prices of the main inputs in the system, we concluded that the cost of inputs affects the performance of the enterprise the most.
\end{abstract}

Keywords: precocity, puberty, Doppler, Nellore, Angus, breed, and NPV

\title{
1. Introduction
}

Age at first calving, the interval between calving and conception, and the interval between services are essential factors for the economic return of investments in breeding a cow for beef cattle activity. In tropical livestock systems based on pasture and zebu breeds, females reach puberty late; consequently, the first calving is delayed (Moreira et al., 2015). Ferraz Junior (2016) evaluated the effect on puberty of the interaction between genetics and average daily weight gain (ADG). In his study, only $84 \%$ of Nellore females under high ADG reached puberty before 19 months. In the same period, 100\% of the Nellore x Angus females reached puberty, highlighting that only Nellore heifers with favorable genetic merit for precocity were able to attain puberty by 18 months of age; on other hand, later heifers were unable to reach puberty below 24 months, even when submitted to high ADG (Ferraz et al., 2018).

Fixed-timed artificial insemination (TAI) is a tool that shortens the interval between delivery and conception (Baruselli et al., 2018). In TAI, the interval between services depends on the time of pregnancy diagnosis. Currently, the most commonly used diagnostic technique is conventional ultrasound, in which the interservice interval is 30 days (Beal et al., 1992; Quintela et al., 2012). However, Pugliesi et al. (2014) used color Doppler ultrasound for the 
diagnosis of pregnancy, 20 days post-insemination, with an interservice interval of 22 days.

Market price analysis of products and services and their fluctuations are also important for planning and evaluating agricultural activities. According to Campos (2007), the market prices of agricultural products are characterized by sharp price fluctuations, causing instability in the farmer's profitability.

Within this context, determining the economic viability of combining nutritional and reproductive technologies in beef cattle is not a simple task. The large number of interacting variables and long production cycles make the process difficult. Therefore, supporting systems redesign by focusing on simulation are particularly relevant. The aim of this study was to determine the effect on the economic viability of representative commercial farms dedicated to the production of Nellore or Nellore x Angus crossbred calves, by: i) reducing time at which females reach puberty through different nutritional strategies; ii) diagnosing pregnancy conventionally at 30 days or earlier using color Doppler ultrasound; and iii) analyzing the influence of deflated historical prices of inputs and outputs faced by farmers.

\section{Material and Methods}

With a calculation method performed by Microsoft ${ }^{\circledR}$ Office Excel® (Version 2010), a deterministic model was developed to simulate the dynamics of a productive unit (representative commercial farm in Brazil) dedicated to beef cattle breeding. The size of the simulated production unit was 500 hectares, with a capacity of 3.30 animal units ha $^{-1}$ and approximately 1,800 reproductive cows. The pastures were arranged in an intensive system with fertilization of $50 \mathrm{~kg}$ of nitrogen and potassium $\mathrm{ha}^{-1}$ year $^{-1}$. The simulated time horizon was 15 years, analyzed at weekly intervals.

The annual health plan considered vaccines to immunize livestock against diseases caused by clostridia, bovine brucellosis (Brucella abortus, strain B-19), and foot-and-mouth disease (Aphtae epizooticae). For the control of endoparasites and ectoparasites, ivermectin products (each $\mathrm{mL}$ contains $10 \mathrm{mg}$ of ivermectin) were used in adults and calves over five months. In newborn calves, this control was performed with doramectin products (each $\mathrm{mL}$ contains 10 mg of doramectin).

It was estimated that four employees and one veterinarian were hired to carry out the different daily activities of herd management, with full monthly salaries of $R \$ 2,040$ and $R \$ 5,792$, respectively, considering all labor taxes and charges. In this paper, the conversion of the Brazilian currency (Real, R\$) to the US Dollar (US\$) followed the conversion rate US\$ 1.00 $=\mathrm{R} \$ 3.4985$, which was the average value of the official exchange rate of Brazil during 2016.

The estimation of the number of capital goods (inventory of physical assets) and inputs was based on literature parameters and the authors' field experience. Input and product prices were obtained from the database of the Institute of Agricultural Economics of the State of São Paulo (IEA, 2016) and the Center for Advanced Studies in Applied Economics (CEPEA, 2016). Prices not found in the IEA or CEPEA databases were obtained from other sources such as the Brazilian Livestock Yearbook (ANUALPEC, 2014) or through direct consultation with traders and farmers in the state of São Paulo. 


\section{Ml Macrothink}

Journal of Agricultural Studies

ISSN 2166-0379

2020, Vol. 8, No. 1

Reproductive management was organized in a breeding season that began on week 35 of the year and lasted for 120 days. The program was based exclusively on the use of TAI. In all of the simulations, the following synchronization protocol was applied to cows. The follicular growth was synchronized with the insertion of an intravaginal P4 device (1.0 g of P4; Sincrogest; Ouro Fino Saúde Animal) through an intramuscular (i.m.) estradiol benzoate injection (2.0 mg; Syncrodiol; Ouro Fino Saúde Animal). Eight days later, the P4 device was removed and animals were treated with i.m. PGF2a (500 $\mu \mathrm{g}$ of sodium cloprostenol), estradiol cypionate (1.0 mg; SincroCP; Ouro Fino Saúde Animal), and equine chorionic gonadotropin (300 IU; Sincro eCG; Ouro Fino Saúde Animal). Cows were artificially inseminated two days after device removal. The simulation model considered two options for pregnancy diagnosis: conventional transrectal ultrasound performed 30 days after TAI, with $100 \%$ accuracy in diagnosis; and color Doppler ultrasonography performed 20 days after TAI with 91\% accuracy (Pugliesi et al., 2014). The number of inseminations during the breeding season depended on the technique used for pregnancy diagnosis. Therefore, three inseminations were used in scenarios with conventional ultrasound, and four inseminations were used in scenarios with color Doppler ultrasound. For both cases, the resynchronization program started the day of pregnancy diagnosis. The resynchronization protocol followed the same methodology as the first TAI.

The values for the parameters of performance and management of young females followed the study of Ferraz Junior (2016). Other productive and reproductive parameters used in the model are presented in Table 1.

Table 1. Productive and reproductive parameters used in simulated commercial farms dedicated to rearing Nellore cattle and Nellore x Angus crossbred cattle

\begin{tabular}{lc}
\hline Parameter & $\%$ \\
\hline Annual adult mortality & 2.00 \\
Monthly adult mortality & 0.10 \\
Cow replacement & 13.00 \\
Annual heifers' mortality & 1.00 \\
Monthly heifers' mortality & 0.08 \\
Weaning rate & 97.00 \\
Birth rate & 92.50 \\
Calves mortality rate & 3.00 \\
$\%$ of males born & 50.00 \\
$\%$ of females born & 50.00
\end{tabular}

In the first and second TAI, the conception rates used were those described by Marques et al. (2015) (Table 2). As an indication of a conception rate after the third TAI was not found, we established $45 \%$ as a standard for subsequent inseminations in all categories (Table 2). 


\section{Macrothink}

Table 2. Conception rate $(\%)$ in the first, second, and third timed artificial insemination (TAI) used in this study for the categories heifers, primiparous cows, and cows.

\begin{tabular}{lccc}
\hline \multirow{2}{*}{ Animal category } & \multicolumn{3}{c}{$\mathrm{TAI}^{1}(\%)$} \\
\cline { 2 - 4 } & 1 st & 2nd & $3^{\text {rd }}$ and 4th \\
\hline Heifers & 57 & 66 & 45 \\
Primiparous cows & 51 & 51 & 45 \\
Cows & 56 & 51 & 45 \\
\hline
\end{tabular}

$\mathrm{TAI}^{1}$ : Timed artificial insemination

The herd dynamics begin with the acquisition, on week 28, of virgin heifers ready for breeding. After seven weeks, the reproductive season begins. Pregnancy time was set at 44 weeks for all categories. Pregnancy losses were estimated at $7.5 \%$. Females who lost a pregnancy could return to the reproductive program. After delivery, the voluntary waiting period was set at eight weeks. Regarding the management of young animals, the number of females needed to keep the herd stable, called replacement females, was calculated and later this number of females was weaned early at 13 weeks of life. After early weaning, as described by Ferraz Junior (2016), heifers were confined and offered one out of the four nutritional strategies until reaching puberty, according to the proposed scenario. The heifers that did not reach puberty at 19 months were discarded and eliminated from the system. The nutritional strategies are described later. The remaining animals in this category, females and males, remained in the herd for a 30-week period, during which they were weaned, sold, and left the system. After reaching puberty, confined females change to the "heifers" category and thus begin their reproductive life, entering their first breeding season and following the same cycle.

With this information, 144 scenarios were constructed to assess the impact of four independent groups of variables (genetic, nutritional strategy, pregnancy diagnosis technique, and market prices) on the technical and economic performance of the herd (Figure 1), represented by the net present value (NPV). 


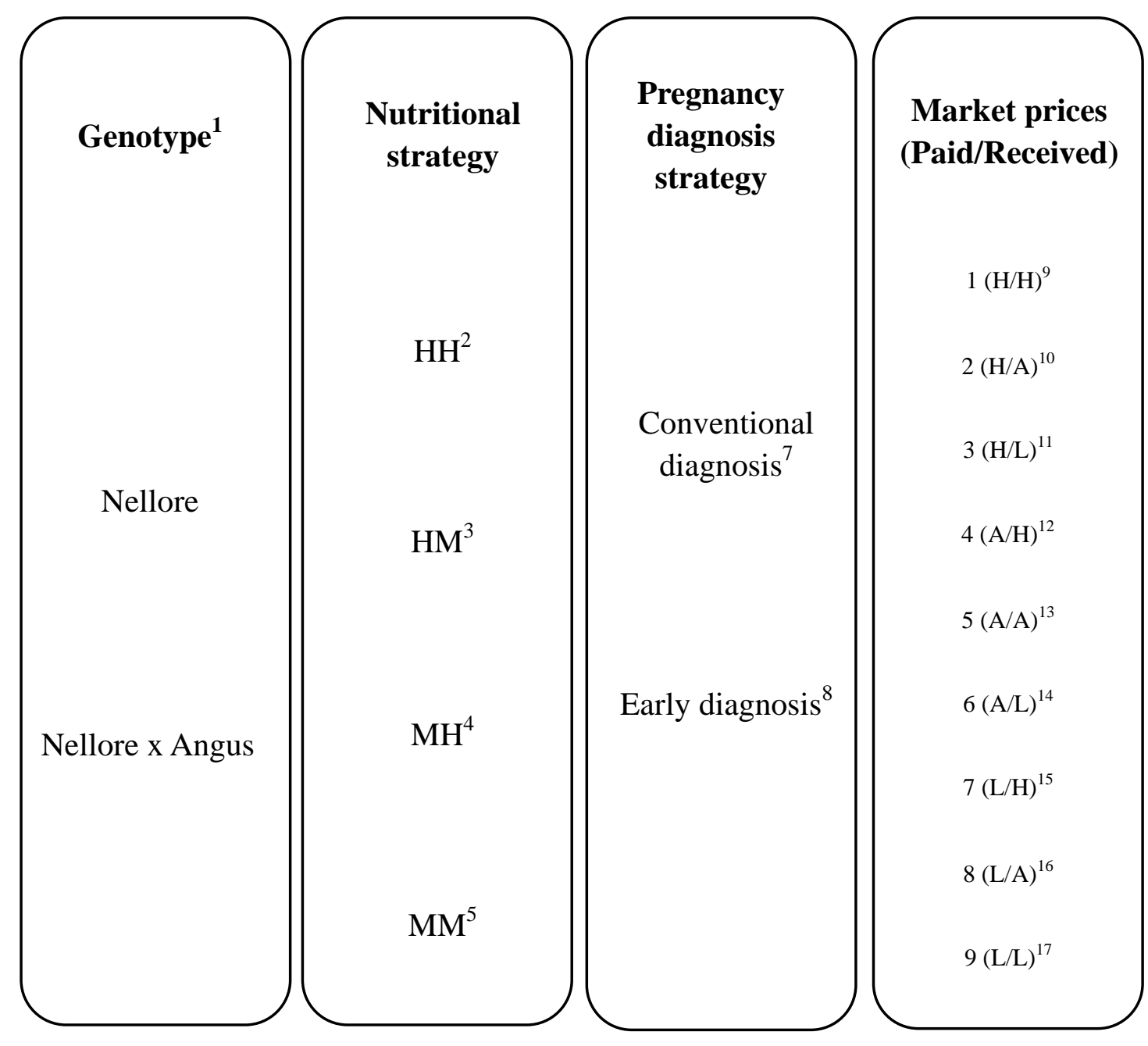

Figure 1. Scenarios considered in the simulation model

${ }^{1}$ Nellore animals and Nellore x Angus crossbreed animals; ${ }^{2}$ High average daily gain (ADG) from three to seven months and high ADG from seven months to puberty; ${ }^{3}$ High ADG from three to seven months and medium ADG from seven months to puberty; ${ }^{4}$ Medium ADG from three to seven months and high ADG from seven months to puberty; ${ }^{5}$ Medium ADG from three to seven months and medium ADG from seven months to puberty; ${ }^{7}$ Conventional ultrasound performed 30 days after TAI; ${ }^{8}$ Color Doppler ultrasound performed 20 days after TAI; ${ }^{9}$ Highest paid prices vs. highest received prices by farmer; ${ }^{10}$ Highest paid prices vs. average prices received by farmer; ${ }^{11}$ Highest paid prices vs. lowest prices received by farmer; ${ }^{12}$ Average paid prices vs. highest prices received by farmer; ${ }^{13}$ Average paid prices vs. average prices received by farmer; ${ }^{14}$ Average paid prices vs. lowest prices received by farmer; ${ }^{15}$ Lowest paid prices vs. highest prices received by farmer; ${ }^{16}$ Lowest paid prices vs. average prices received by farmer; ${ }^{17}$ Lowest paid prices vs. lowest prices received by farmer.

The criteria for setting the scenarios were: two genetic groups, Nellore animals and Nellore $\mathrm{x}$ Angus crossbreed animals. Nutritional management was composed of two ADG (500 g day ${ }^{-1}$ and 1,000 $\mathrm{g} \mathrm{day}^{-1}$ ) and two growth stages (from three to seven months of age and from seven months to puberty), resulting in four nutritional strategies: high ADG from three to seven 
months and high ADG from seven months to puberty $(\mathrm{HH})$; high ADG from three to seven months and medium ADG from seven months to puberty (HM); medium ADG from three to seven months and high ADG from seven months to puberty (MH); and medium ADG from three to seven months and medium ADG from seven months to puberty (MM) (Ferraz Junior, 2016). Two strategies for pregnancy diagnosis, conventional ultrasonography performed 30 days after TAI with 100\% accuracy, and color Doppler ultrasound performed 20 days after TAI with 91\% accuracy (Pugliesi et al., 2014), were used. In scenarios where the pregnancy was diagnosed using conventional ultrasound, three TAIs were performed. In contrast, in scenarios where pregnancy diagnosis was made by Doppler ultrasonography, four TAIs were performed. Nine relative market price scenarios were derived: scenario 1 (highest paid prices versus highest prices received by farmer); scenario 2 (highest paid prices vs. average prices received by farmer); scenario 3 (highest paid prices vs. lowest prices received by farmer); scenario 4 (average paid prices vs. highest prices received by farmer); scenario 5 (average paid prices vs. average prices received by farmer); scenario 6 (average paid prices vs. lowest prices received by farmer); scenario 7 (lowest paid prices vs. highest prices received by farmer); scenario 8 (lowest paid prices vs. average prices received by farmer); scenario 9 (lowest paid prices vs. lowest prices received by farmer). All prices were deflated to August 2016 by using the National Consumer Price Index (IBGE, 2016), generating the monthly historical averages used in the calculations. Table 3 presents the deflated historical prices paid and received by producers.

Table 3. The lowest, average, and highest deflated prices (in Brazilian currency), paid and received by producers in the last 10 years, used to assess the economic efficiency of precocity in puberty and pregnancy diagnosis

\begin{tabular}{lrrrr}
\hline \multirow{2}{*}{ Item } & \multicolumn{1}{c}{ Unit } & \multicolumn{3}{c}{ Historical price (R\$) } \\
\cline { 3 - 5 } Paid prices & & Lowest & Average & Highest \\
\hline Corn & $\mathrm{Kg}$ & 0.55 & 0.65 & 0.82 \\
Soybean meal & $\mathrm{Kg}$ & 0.95 & 1.32 & 1.64 \\
Cotton meal 48\% & $\mathrm{Kg}$ & 1.29 & 1.33 & 1.40 \\
Mineral salt & $\mathrm{Kg}$ & 1.63 & 2.14 & 2.34 \\
Ammonium Sulfate & Ton & $1,112.04$ & $1,421.34$ & $1,887.77$ \\
Urea & Ton & $1,887.37$ & $2,230.60$ & $2,492.95$ \\
20-05-20 & Ton & $1,951.77$ & $2,097.00$ & $2,277.38$ \\
Limestone & Ton & 53.50 & 82.21 & 110.04 \\
Rearing cow & Head & $1,175.94$ & $1,685.55$ & $2,198.60$ \\
\hline Received prices & & & & \\
\hline Discarding cow & Head & $1,177.10$ & $1,682.92$ & $2,198.60$ \\
Discarding heifer & Head & 784.46 & $1,158.61$ & $1,509.08$ \\
Calf & Head & 604.70 & $1,032.71$ & $1,472.89$ \\
\hline
\end{tabular}




\section{Ml Macrothink}

Journal of Agricultural Studies

ISSN 2166-0379

2020, Vol. 8, No. 1

The economic viability of the investment in all scenarios studied was analyzed by the cash flow method (Gitman \& Zutter, 2011) for 803 weeks, allowing observation of the economic impacts of the different scenarios over time. It considered inputs (R), which are net inflows of resources to the project (animal sales), minus outputs (C) (expenses and investments). The indicator used to determine the economic viability was NPV (Gitman \& Zutter, 2011). For the calculation of NPV, a weekly discount rate of $0.11 \%$ per month was considered, representative of the historically intended remuneration for savings accounts in Brazil.

Multiple regression was the statistical technique used to construct a model that adequately described the relationships between the various independent variables (genetic group, nutritional strategy, pregnancy diagnosis technique, and relative market prices) and the dependent variable, which was represented by the NPV economic indicator. The general econometric model is represented by Equation 1.

$$
\begin{gathered}
\mathrm{NPV}=\mathrm{a}+\mathrm{b} \cdot \mathrm{GN}+\mathrm{c} \cdot \mathrm{NU} 1+\mathrm{d} \cdot \mathrm{NU} 2+\mathrm{e} \cdot \mathrm{NU} 3+\mathrm{f} . \mathrm{DG}+\mathrm{g} \cdot \mathrm{PR} 1+\mathrm{h} . \mathrm{PR} 2+\mathrm{i} \cdot \mathrm{PR} 3+\mathrm{j} \cdot \mathrm{PR} 4+\mathrm{k} \cdot \mathrm{PR} 5+\mathrm{l} . \mathrm{PR} 6+\mathrm{m} . \\
\mathrm{PR} 7+\mathrm{n} . \mathrm{PR} 8
\end{gathered}
$$

The fact that the explanatory variables are qualitative information justified the use of multiple regression with the presence of qualitative dummy/binary variables. To represent the Nellore genetic group, variable GN (genotype) assumes the value zero, and one for the Nellore $\mathrm{x}$ Angus group. To represent the $\mathrm{HH}$ nutritional strategy (high/high), there is the following combination, $\mathrm{NU} 1=\mathrm{NU} 2=\mathrm{NU} 3=1$; for $\mathrm{HM}$ (high/medium), NU1 = 0 and NU2 = NU3 = 1 ; for $\mathrm{MH}$ (medium/high), NU1 = NU2 = 0 and NU3 = 1; for MM (medium/medium), NU1 = $\mathrm{NU} 2=\mathrm{NU} 3=0$. To represent early diagnosis, the variable DG (pregnancy diagnosis strategy) assumes the value zero, and one for the traditional diagnosis. To represent paid/received prices, there are the following combination of dummies: highest/highest: PR1 $=$ PR2 = PR3 = $\mathrm{PR} 4=\mathrm{PR} 5=\mathrm{PR} 6=\mathrm{PR} 7=\mathrm{PR} 8=1$; highest $/$ average: $\mathrm{PR} 1=0$ and $\mathrm{PR} 2=\mathrm{PR} 3=\mathrm{PR} 4=\mathrm{PR} 5$ $=\mathrm{PR} 6=\mathrm{PR} 7=\mathrm{PR} 8=1$; highest $/$ lowest $\mathrm{PR} 1=\mathrm{PR} 2=0$ and $\mathrm{PR} 3=\mathrm{PR} 4=\mathrm{PR} 5=\mathrm{PR} 6=\mathrm{PR} 7$ $=\mathrm{PR} 8=1$; average/highest: $\mathrm{PR} 1=\mathrm{PR} 2=\mathrm{PR} 3=0$ and $\mathrm{PR} 4=\mathrm{PR} 5=\mathrm{PR} 6=\mathrm{PR} 7=\mathrm{PR} 8=1$; average/average: $\mathrm{PR} 1=\mathrm{PR} 2=\mathrm{PR} 3=\mathrm{PR} 4=0$ and $\mathrm{PR} 5=\mathrm{PR} 6=\mathrm{PR} 7=\mathrm{PR} 8=1$; average/lowest: $\mathrm{PR} 1=\mathrm{PR} 2=\mathrm{PR} 3=\mathrm{PR} 4=\mathrm{PR} 5=0$ and $\mathrm{PR} 6=\mathrm{PR} 7=\mathrm{PR} 8=1$; lowest/highest: $\mathrm{PR} 1=\mathrm{PR} 2=\mathrm{PR} 3=\mathrm{PR} 4=\mathrm{PR} 5=\mathrm{PR} 6=0$ and $\mathrm{PR} 7=\mathrm{PR} 8=1$; lowest/average: $\mathrm{PR} 1=\mathrm{PR} 2=\mathrm{PR} 3=\mathrm{PR} 4=\mathrm{PR} 5=\mathrm{PR} 6=\mathrm{PR} 7=0$ and $\mathrm{PR} 8=1$; and lowest/lowest: PR1 = PR2 = PR3 = PR4 = PR5 = PR6 = PR7 = PR8 = . 


\section{Results and Discussion}

The regression results are presented in Table 4.

Table 4. Coefficient values, standard errors, t-test, and P-values of the multiple regressions performed to find the effect of the explanatory variables on the NPV of the enterprise

\begin{tabular}{lrrrr}
\hline \multicolumn{1}{c}{$\begin{array}{c}\text { Explanatory } \\
\text { variables }\end{array}$} & \multicolumn{1}{c}{$\begin{array}{l}\text { Estimated } \\
\text { coefficients }\end{array}$} & Standard errors & t-test & P-value \\
\hline Constant & $-2,145,453.59$ & $1,560,196.17$ & -1.38 & 0.170 \\
GN $^{1}$ & $6,958,158.18$ & $321,843.89$ & 21.62 & $7.00 \mathrm{E}-45$ \\
NU1 $^{2}$ & $1,389,099.66$ & $455,156.00$ & 3.05 & 0.002 \\
NU2 $^{3}$ & $-960,723.90$ & $455,156.00$ & -2.11 & 0.030 \\
NU3 $^{4}$ & $2,332,780.91$ & $455,156.00$ & 5.13 & $1.04 \mathrm{E}-06$ \\
DG $^{5}$ & $-2,742,576.75$ & $321,843.89$ & -8.52 & $3.41 \mathrm{E}-14$ \\
PR1 $^{6}$ & $7,188,419.18$ & $682,734.00$ & 10.53 & $3.98 \mathrm{E}-19$ \\
PR2 $^{7}$ & $7,090,897.23$ & $682,734.00$ & 10.39 & $9.04 \mathrm{E}-19$ \\
PR3 $^{8}$ & $-18,148,678.82$ & $682,734.00$ & -26.58 & $2.09 \mathrm{E}-54$ \\
PR4 $^{9}$ & $7,216,399.52$ & $682,734.00$ & 10.57 & $3.15 \mathrm{E}-19$ \\
PR5 $^{10}$ & $6,031,194.24$ & $682,734.00$ & 8.83 & $6.00 \mathrm{E}-15$ \\
PR6 $^{11}$ & $-17,053,059.11$ & $682,734.00$ & -24.98 & $1.84 \mathrm{E}-51$ \\
PR7 $^{12}$ & $7,224,220.48$ & $682,734.00$ & 10.58 & $2.95 \mathrm{E}-19$ \\
PR8 $^{13}$ & $7,086,337.67$ & $682,734.00$ & 10.38 & $9.39 \mathrm{E}-19$ \\
\hline${ }^{13}$ & & & & \\
\hline
\end{tabular}

${ }^{1}$ Binary of the genetic groups studied; ${ }^{2,3,4}$ Binaries for nutritional strategy; ${ }^{5}$ Binary for the time at which pregnancy diagnosis is made after TAI; ${ }^{6,7,8,9,10,11,12,13}$ Binaries for relative price levels of inputs and outputs.

\subsection{Effect of the Genetic Group (GN) on the NPV}

The genetic group had a significant effect on the NPV. The Nellore x Angus crossbreeding scenarios had better economic performance and the highest number of weaned and sold calves. The results presented in Table 4 show that Nellore x Angus crossbreeding would add nearly R \$ 7 million to the NPV when compared to Nellore cattle. As previously discussed, the literature indicates advantages in the use of European cattle breeds to increase the biological and economic efficiency of milk and meat production (Gasser et al., 2006; Campos et al., 2013; Moriel et al., 2014; Cardoso et al., 2014; Ferraz et al., 2018). In the specific case of beef cattle, these results support the proposal of using hybrid vigor as an alternative to increasing the offtake rate of the national herd (Souza et al., 2012). 
The number of calves born was not affected by the nutritional strategy, pregnancy diagnosis technique, and relative market prices $(\mathrm{P}>0.05)$. However, the number of weaned calves was different between genetic groups $(\mathrm{P}<0.05)$. In simulated scenarios of the Nellore $\mathrm{x}$ Angus crossbreed, the number of weaned calves was higher than in simulated scenarios of the Nellore breed. This is because more Nellore calves ought to be confined in order to get a good number of pubertal heifers to keep the herd stable. Unlike Nellore x Angus heifers, not all Nellore heifers reach puberty after the feedlot period. Campos et al. (2013) evaluated the effect of zootechnical indicators on the performance of a highly technically productive unit in which 1,305 cows were kept in an area of 1,570.58 hectares in pasture, with hybrid cows (Bos indicus x Bos taurus), mainly from Nellore (NE), Aberdeen Angus (AA), and Red Angus (RA) breeds, with blood levels of $1 / 2 \mathrm{NE} 1 / 2 \mathrm{AA}$ and $1 / 2 \mathrm{NE} 1 / 2 \mathrm{RA}$. The results obtained by these authors show that Nellore crossbreeds with European breeds offer better reproductive parameters, which consequently will be reflected in the more significant number of calves produced in the system. In addition, only Nellore heifers with favorable genetic merit for precocity were able to attain puberty before 18 months of age (Ferraz et al., 2018). The Nellore breed may be considered a breed that reaches sexual precocity later, as normally, heifers reach puberty after 24 months of age (Nepomuceno et al., 2017).

On the other hand, the number of females discarded was not influenced by any of the independent variables $(\mathrm{P}>0.05)$. In the simulated scenarios of the Nellore breed, however, an additional source of income was the sale of those discarded heifers who did not reach puberty after the feedlot period. When comparing the total number of females discarded for reproductive reasons, a difference was found between the genetic groups, being higher in the simulated scenarios of the Nellore breed $(\mathrm{P}<0.05)$. Although the larger number of discarded heifers generated a good capital inflow in these simulated scenarios, this was not enough to improve economic viability when compared to the simulated scenarios with Nellore $\mathrm{x}$ Angus crossbreeding. These results support two arguments: i) Precocity is one of the desired characteristics for increasing economic efficiency in calf rearing systems (Formigoni et al., 2005; Reggiori et al., 2016); ii) Adequate nutrition in the growing season is essential to advance puberty, this effect being more noticeable in Angus females or their crossbreeds (Gasser et al., 2006; Moriel et al., 2014; Cardoso et al., 2014; Ferraz et al., 2018).

\subsection{Effect of the Nutritional Strategy on the NPV}

The HH strategy was the one that had the best effect on the NPV, with an estimated increase of R \$2,761,156.67 on NPV compared to the MM strategy (result of 1,389,099.66 - 960,723.90+ 2,332,780.91). The second-best effect on NPV was observed in the MH strategy (+ $\mathrm{R} \$ 2,332,780.91)$ and finally in the HM $(-960,723.90+2,332,780.91=\mathrm{R} \$ 1,372,057.01)$. From the economic perspective, our results follow those of Ferraz Junior (2016). For dairy cattle, it has been shown that adequate nutrition in the rearing stage is a key factor for increasing the environmental and financial sustainability of milk production systems (Margerison et al., 2013; Peres et al., 2015). Our study suggests the economic viability of balanced nutrition in enterprises dedicated to beef cattle raising.

As expected, diets that offered high ADG had higher costs due to higher consumption of 
concentrated feed. Thus, the effort and the investment required to offer any of the growth rates (HH, HM, MH, or MM) were not considered to be a viable option from the zootechnical and economic point of view, for both the Nellore breed and the Nellore x Angus crossbreed, according to the results obtained in the scenarios considered to be representative of the Brazilian reality (average paid prices vs. average received prices). Actually, achieving economic viability in production units dedicated to beef cattle is challenging. As will be explained later, the price of inputs and products are determining factors for the success of the farmer. Therefore, as Peres et al. (2015) did, we recommend that the farmer works with a focus on precision farming, as this approach will be able to efficiently manage resources, avoid excesses, and make the right decisions.

The fixed and variable costs generated in the simulation did not vary significantly by the effect of the independent variables in the model $(\mathrm{P}>0.05)$. Herd feeding and supplementation were the highest costs in all simulated scenarios (on average $65 \%$ of total production costs). In contrast, reproductive programs and health plans represented, on average, only $4 \%$ and $3 \%$, respectively. Further analyzing the costs generated by feeding, it was observed that the maintenance of pastures summed up to $48 \%$ of this item, while herd supplementation during the drought period and the feedlot of replacement heifers accounted for $31 \%$ and $21 \%$, respectively. In the results of a bioeconomic model developed by Campos et al. (2014), it is possible to observe that the highest expenses in the system were also generated by pasture management, feeding, and herd supplementation. However, for Campos et al. (2014), these variable costs represented only $33 \%$ of total production costs - the difference among them is a consequence of the intensification level attributed to each simulated scenario. This study explored the use of a feedlot system and supplementation as a strategy to maintain approximately 1,800 rearing cows per year on a 500 hectares area.

\subsection{Effect of Pregnancy Diagnosis Strategy on the NPV}

The traditional diagnosis with conventional ultrasound had a negative effect on the NPV, estimated at minus $\mathrm{R} \$ 2,742,576.75$ in comparison to the strategy that would use early diagnosis with color Doppler. It means that conducting the diagnosis earlier would increase the NPV of the business by approximately R $\$ 2.7$ million. A similar trend was found by Giordano et al. (2013) after creating different scenarios in the "UW-Dairy Repro\$" program, developed by the University of Wisconsin, Madison, USA, to determine the economic viability of three techniques for pregnancy diagnosis (rectal palpation, transrectal ultrasound, and ELISA-PAG chemical test). Under these conditions, the authors mention that the test that offered the earliest diagnosis of pregnancy (ELSA-PAG chemical test) had the best effect on the NPV economic indicator. Other studies also show results on the biological and economic advantages of accurately anticipating pregnancy diagnosis (Galligan et al., 2009; Green et al., 2011; Abdulkareem et al., 2012).

The early pregnancy diagnosis allowed earlier calving, reduction of the interval between services and, consequently, anticipation of the timing of inflows in cash flow by events such as the sale of weaned calves, discarded heifers, and cows. In other words, the scenarios where the pregnancy diagnosis was made earlier allowed a faster return on the invested capital. Working 
in intensive cattle breeding systems brings challenges with it since the number of inputs used in the system increases and, thus, the need for invested capital. However, even at higher costs, the results indicate that the advance in revenues outweighs higher production costs.

\subsection{Effect of Overall Relative Price Level on the NPV}

The results show relatively evident effects, with higher input prices (paid prices) and lower prices for products (received prices) tending to worsen the results and vice versa. The scenario that should be considered as the most representative of reality is the one in which the prices paid and received are the historical averages. Under these conditions, the effect of the price level had a positive influence on the NPV of approximately R $\$ 3.8$ million.

Our study concludes that market prices of inputs and products are the most important in defining the economic viability of enterprises - the same conclusion that other authors have also found (Campos et al., 2014; Peres et al., 2015). It is, therefore, empirical evidence aligned with: i) economic theory, through which the market can be classified as very competitive and therefore with very low and often negative margins; and with ii) the sector agents' impressions that the rearing activity is perhaps the most sensitive in Brazilian beef cattle, since they imply relatively high investment and fixed capital, along with the low productivity (of calves) for income generation.

\subsection{Effect of the Constant on the NPV}

Finally, we must analyze the value of the constant estimated by the multiple regression model, which was equal to $-2,145,453.59$. The constant represents the fixed factor over the NPV. This is a very high value with a negative sign, meaning that, except for the effects of explanatory variables (genetics, nutritional strategy, pregnancy diagnosis technique, and general price levels), the NPV of the cattle production enterprise tends to present a high fixed cost, around $\mathrm{R} \$ 2.1$ million, in order to make the business viable during the 803 weeks that our study lasted.

The explanation for this high production cost is found in the time zero $(\mathrm{t}=0)$ of the cash flow. To start the business, it was necessary to invest in the purchase of breeding cows and production factors, which generated a very expressive output in the different scenarios. In terms of amounts, the outflow or the initial investment value was of $\mathrm{R} \$ 5,578,848.83$ in the scenarios with the highest prices paid by the farmer; $\mathrm{R} \$ 4,504,327.44$ in the scenarios with the average paid prices; and $\mathrm{R} \$ 3,436,281.29$ in the scenarios with the lowest paid prices.

\section{Final Considerations}

Through simulations, our study provides evidence of the economic fragility of the beef cattle rearing phase. The initial investment is relatively high, significant expenses are generated daily (mainly by feeding the herd), and the primary input, which is the result of the sale of weaned calves, only happens at certain times of the year.

After comparing the diagnosis of color Doppler pregnancy to transrectal ultrasound, it was observed that this latest technique allows the inclusion of one more TAI protocol per breeding season, which increases the NPV of the project by approximately R $\$ 2.7$ million. 
All simulated scenarios for Nellore $\mathrm{x}$ Angus crossbreeding presented a better NPV than simulated scenarios for the Nellore breed. The reason is that all Nellore $x$ Angus confined heifers reached puberty after feedlot and even earlier when compared to the Nellore.

The nutritional strategy that offered the highest growth rate in the two phases of the feedlot of weaned calves $(\mathrm{HH})$ was the one that had the best effect on the NPV, estimated at an increase of $\mathrm{R} \$ 2,761,156.67$ when compared to the MM strategy. Finally, the analysis of the historical prices paid and received by farmers in the last 10 years showed that the price of inputs (as for pasture maintenance and concentrate supplementation) was the main factor responsible for determining the viability of these production systems.

\section{References}

Abdulkareem, T. A., Eidan, S. M., Ishak, M. A., Al-sharifi, S. A. M., Alnimer, M. A., \& Passavant, C. W. (2012). Pregnancy-specific protein B (PSPB), progesterone and some biochemical attributes concentrations in the fetal fluids and serum and its relationship with fetal and placental characteristics of Iraqi riverine buffalo (Bubalus bubalis). Animal and Reproduction Science, 130, 33-41. https://doi.org/10.1016/j.anireprosci.2012.01.002

ANUALPEC. (2014). Anuário da pecuária brasileira. São Paulo: Informa Economics FNP, $2015,280$.

Baruselli, P. S., Ferreira, R. M., Sá Filho, M. F., \& Bó, G. A. (2018). Review: Using artificial insemination v. natural service in beef herds. Animal, 12, 45-52. https://doi.org/10.1017/S175173111800054X

Beal, W. E., Perry, R. C., \& Corah, L. R. (1992). The use of ultrasound in monitoring reproductive physiology of beef cattle. Journal of Animal Science, 70(3), 924-929. https://doi.org/10.2527/1992.703924x

Campos, A. M., Leão, K. M., Cabral, J. F., Carvalho, T. S., Brasil, R. B., \& García, J. C. (2013). Índices zootécnicos da fase de cria de uma propriedade de gado de corte tecnificada. Ciências Agrárias e Biológicas, 7 (1).

Campos, G. S., Braccini, N. J., Oaigen, R. P., Cardoso, F. F., Cobuci, J. A., Kern, E. L., ... McManus, C. M. (2014). Bioeconomic model and selection indices in Aberdeen Angus cattle. Journal of Animal Breeding and Genetics, 131, 305-312. https://doi.org/10.1111/jbg.12069

Campos, K. C. (2007). Análise da volatilidade de preços de produtos agropecuários no brasil. Revista de Economia e Agronegócio, 5 (3), 303-328.

Cardoso, R. C., Alves, B. R. C., Prezotto, L. D., Thorson, J. F., Tedeschi, L. O., Keisler, D. H., ... Williams, G. L. (2014). Use of a stair-step compensatory gain nutritional regime to program the onset of puberty in beef heifers. Journal of Animal Science, 92, 2942-2949. https://doi.org/10.2527/jas.2014-7713

CEPEA (2016). Centro de Estudos Avançados em Economia Aplicada), Database. http://www.cepea.esalq.usp.br/br> 
Ferraz Junior, M. V. C. (2016). Puberdade de novilhas: 1 - Efeito da nutrição e da DEP do touro para precocidade sexual na puberdade de novilhas Nelore; 2 - Efeito da desmama precoce e da nutrição no imprinting metabólico sobre a puberdade de novilhas Nelore e cruzadas (Angus x Nelore). 2016. 97 f. Tese (Doutorado em Ciências) - Faculdade de Medicina Veterinária e Zootecnia, Universidade de São Paulo, Pirassununga.

Ferraz, M. V. C., Pires, A. V., Santos, M. H., Silva, R. G., Oliveira, G. B., Polizel, D. M., ... Nogueira, G. P. (2018). A combination of nutrition and genetics is able to reduce age at puberty in Nelore heifers to below 18 months. Animal, 12, 569-574. https://doi.org/10.1017/S1751731117002464

Formigoni, I. B., Ferraz, J. B. S., Silva, J. A. II. V., Eler, J. P., \& Brumatti, R. C. (2005). Valores econômicos para habilidade de permanência e probabilidade de prenhez aos 14 meses em bovinos de corte. Arquivo Brasileiro de Medicina Veterinária y Zootecnia, 57(2), 220-226. https://doi.org/10.1590/S0102-09352005000800013

Galligan, D. T., Ferguson, J., Munson, R., Remsburg, D., \& Skidmore, A. (2009). Economic concepts regarding early pregnancy testing. In: Annual conference of the American association of bovine practitioners, 42, Omaha. Proceedings.... Auburn: A.A.B P, 48-53.

Gasser, C. L., Behlke, E. J., Grum, D. E., \& Day, M. L. (2006). Effect of timing of feeding high concentrate diet on growth and attainment of puberty in early-weaned heifers. Journal of Animal Science, 84, 3118-3122. https://doi.org/10.2527/jas.2005-676

Giordano, J. O., Fricke, P. M., \& Cabrera, V. E. (2013). Economics of resynchronization strategies including chemical tests to identify nonpregnant cows. Journal of Dairy Science, 96, 949-961. https://doi.org/10.3168/jds.2012-5704

Gitman, L. J., \& Zutter, C. J. (2011). Principles of Managerial Finance: Vol. 13. New Jersey: Prentice Hall.

Green, J. C., Newsom, E. M., \& Lucy, M. C. (2011). Incorporation of a rapid pregnancy-associated glycoprotein ELISA into a CIDR-Ovsynch resynchronization program for a 28 day re-insemination interval. Theriogenology, 75, 320-328. https://doi.org/10.1016/j.theriogenology.2010.09.002

IBGE (2016). Instituto Brasileiro de Geografia e Estatística. http://www.ibge.gov.br/

IEA (2016). Instituto de Economia Agrícola, Database. http://www.iea.sp.gov.br/out/index.php

Margerison, J. K., Robarts, A. D. J., \& Reynolds, G. W. (2013). The effect of increasing the nutrient and amino acid concentration of milk diets on dairy heifer individual feed intake, growth, development, and lactation performance. Journal of Dairy Science, 96, 6539-6549. https://doi.org/10.3168/jds.2012-6489

Marques, M. O., Morotti, F., Silva, C. B., Junior, M. R., Silva, R. C. P., Baruselli, P. S., \& Seneda, M. M. (2015). Influence of category-heifers, primiparous and multiparous lactating cows in a large-scale resynchronization fixed-time artificial insemination program. Journal of Veterinary Science, 16(3), 367-371. https://doi.org/10.4142/jvs.2015.16.3.367 
Moreira, H. L., Buzanskas, M. E., Munari, D. P., Canova, E. B., Lobo, R. B., \& Paz, C. C. P. (2015). Reproductive traits selection in Nellore beef cattle. Ciência e Agrotecnologia, 39(4), 355-362. https://doi.org/10.1590/S1413-70542015000400006

Moriel, P., Johnson, S. E., Vendramini, J. M. B., Mercadante, V. R. G., Hersom, M. J., \& Arthington, J. D. (2014). Effects of calf weaning age and subsequent management system on growth and reproductive performance of beef heifers. Journal of Animal Science, 92, 3096-3107. https://doi.org/10.2527/jas.2013-7389

Nepomuceno, D. D., Pires, A. V., Ferraz, M. V. C., Biehl, M. V., Gonçalves, J. R. S., Moreira, E. M., \& Day, M. L. (2017). Effect of pre-partum dam supplementation, creep-feeding and post-weaning feedlot on age at puberty in Nellore heifers. Livestock Science, 195, 58-62. https://doi.org/10.1016/j.livsci.2016.11.008

Peres, A. A. C., Santos, A. A., Carvalho, C. A. B., \& Brandalise, N. (2015). Análises financeira de sistemas de produção para novilhas em pastagem de Brachiaria brizantha 'Xaraés' suplementadas com mistura mineral. Archivo de Zootecnia, 64, 123-130. https://doi.org/10.21071/az.v64i246.386

Pugliesi, G., Miagawa, B. T., Paiva, Y. N., Franca, M. R., Silva, L. A., \& Binelli, M. (2014). Conceptus-induced changes in the gene expression of blood immune cells and the ultrasound-accessed luteal function in beef cattle: how early can we detect pregnancy? Biology of Reproduction, 91(4), 95. https://doi.org/10.1095/biolreprod.114.121525

Quintela, L. A., Barrio, M., Peña, A. I., Becerra, J. J., Cainzos, J., Herradón, P. G., \& Díaz, C. (2012). Use of ultrasound in the reproductive management of dairy cattle. Reproduction in Domestic Animals, 47, 34-44. https://doi.org/10.1111/j.1439-0531.2012.02032.x

Reggiori, M. R., Torres Junior, R. A. A., Menezes, G. R. O., Battistelli, J. V. F., Silva, L. O. C., Alencar, M. M., ... Faria, F. J. C. (2016). Precocidade sexual, eficiencia reprodutiva e desempenho produtivo de matrizes jovens Nelore y cruzadas. Arquivo Brasileiro de Medicina Veterinária y Zootecnia, 68(6), 1563-1572. https://doi.org/10.1590/1678-4162-8933

Souza, E. J. O., Valadares, F., S. C., Guim, A., Valadares, R. F. D., Paulino, P. V. R., Ferreira, M. A., ... Lage, J. F. (2012). Taxa de deposição de tecidos corporais de novilhas Nelore e suas cruzas com Angus y Simental. Revista Brasileira de Saúde e Produção Animal, 13(2), 344-359. https://doi.org/10.1590/S1519-99402012000200005

\section{Copyright Disclaimer}

Copyright for this article is retained by the author(s), with first publication rights granted to the journal.

This is an open-access article distributed under the terms and conditions of the Creative Commons Attribution license (http://creativecommons.org/licenses/by/4.0/). 